\title{
Methodology Development of the University Teacher's Creative Abilities with the Help of Information Technologies
}

\author{
Sergeeva M.G. ${ }^{1}$, Ogurechnikova N.L ${ }^{2}$, Zarembo G.V. ${ }^{3}$, Nikashina N.V. ${ }^{4}$, Nagornova E.V. ${ }^{5}$, Vasilenko \\ S.A. ${ }^{6}$, Baranova E.A. ${ }^{7}$ \\ ${ }^{1}$ Doctor of Pedagogical Sciences, Associate Professor, senior researcher; Federal State Institution "Research \\ Institute of the Federal Penitentiary Service of Russia", Russia, nii @fsin.su, \\ ${ }^{2}$ Doctor of Philological Sciences, Associate Professor, Peoples' Friendship University of Russia (RUDN \\ University), Russia, information@rudn.ru, \\ ${ }^{3}$ Candidate of Psychological Sciences, Associate Professor, Peoples' Friendship University of Russia (RUDN \\ University), Russia, information@rudn.ru, \\ ${ }^{4}$ Candidate of Philological Sciences, Associate Professor, Peoples' Friendship University of Russia (RUDN \\ University), Russia, information @ rudn.ru, \\ ${ }^{5}$ Candidate of Philological Sciences, Associate Professor, Peoples' Friendship University of Russia (RUDN \\ University), Russia, information@ rudn.ru, \\ ${ }^{6}$ Candidate of Philosophical Sciences, Associate Professor, Peoples' Friendship University of Russia (RUDN \\ University), Russia, information@ @rudn.ru, \\ ${ }^{7}$ Candidate of Pedagogical Sciences, Associate Professor, K.G. Razumovsky Moscow State University of \\ Technologies and Management (the First Cossack University), Russia, rektorat@ mgutm.ru
}

\section{ABSTRACT}

Pedagogical activity implies persistent perfection of professional skills and expertise, caused by extensive use of information and communication technologies in the educational process, which requires a creative approach in work. The innovative work mode in the conditions of total digitizing of education brings about different one-off circumstances which are not included into the existing methodology. The pedagogue's task is to use professional and creative qualities in order to find a true recipe for solving arisen problems with the use of computer technologies. This is what determines the requirements to the modern pedagogue in terms of continuous development of his/her creative thinking. In the conditions of the changing educational paradigm, building a creative educational environment for learning foreign languages take on particular significance as it facilitates both the development of the learner's initial creative potential and his/her further growth as a linguistic persona and an increase of aspiration to life-long self-development. The main requirements to the digital educational environment are a high level of uncertainty and problem, continuity and consistency, accepting the learner and involving him/her into an active educational process. The distinctive features of the digital didactic language environment, which is a foreign language educational space, are the communicative approach to the educational process, as well as pragmatic, developmental, action-oriented, personality-focused character of education. Creative teaching of language in the conditions of digital educational environment results positively, it facilitates stable interest in and motivation to learning a foreign language, the development of creative thinking and creative abilities, the evolvement of a second-
\end{abstract}

language persona, and is a guarantee of successful professional, social and personal self-realization.

Key words: a foreign language teacher, creative abilities, creativity, digital educational environment.

\section{INTRODUCTION}

In the most generalized way, creative abilities by modern psychological and pedagogical science to be equal to the notion of creativity are considered, which is understood as a common, diagnostically verified ability to create. The most accepted definition of this phenomenon is an individual's ability to generate extraordinary ideas, find original solutions, and go off the bitten track. The prominent researcher of this problem D.B. Bogoyavlenskaya says that the principal suddenness of a creative process makes it very elusive for scientific methods. This suddenness is both in the inability to predict the moment of the flash and creative solution and in the unexpectedness of the subject of creativity itself, of the creative idea, which can appear beyond the connection with the learning activity: "in order to create one should think beside". Creativity is also in creative abilities, which appear themselves in thinking, feelings and particular activities. They characterize a personality as a whole and its particular sides, activity process and activity results. It is important to distinguish between creation and creativity. Creation is primary and fundamental. The main constituent of a creative product is its pragmatic element, i.e. understanding why something has to be created and what exactly should be created [1-13]. 


\section{LITERATURE REVIEW}

The study into the development of the pedagogue's creative abilities is described in the works of many Russian and foreign scientists, such as J. Guilford, E. Torrance, C. Rogers, A.N. Leontiev, L.S. Vygotsky, S.L. Rubinstein, Y.A. Ponomarev, S.A. Mednik, B.M. Teplov, V.N. Druzhinin, V.S. Yurkevich, D.B. Bogoyavlenskaya, M.A. Kholodnaya, T.A. Barysheva, etc.

Contemporary psychology conducts research of particular parameters of creative character (personal aspects, sensitivity, image thinking, etc.). However, as the researches by B.G. Ananiev and N.A. Nosov show, the separated study of the qualities, processes and functions is not always productive, because real creative behavior is largely determined not by particular psychological qualities, but by more complex units, which as well include creativity. B.G. Ananiev underlined the universal, systemwide character of interaction between energy, information and different psychological qualities in the human consciousness and existence.

At present, the most accepted typology of the notion "creativity" suggests:

1. Creativity is the personality's general characteristic, but not a complex of interconnected personal characteristics (A. Maslow, C. Rogers, F. Barron, D. Wechsler, R. Weisberg, H.J. Eysenck, M.A. Kholodnaya, V.N. Druzhinin, S.A. Mednik, G.A. Glotova, O.A. Kholifaeva).

2. Creativity is the ability to generate many diverse original ideas in unconventional circumstances (M.A. Kholodnaya, V.N. Druzhinin, F. Barron).

3. Creativity is an internal potential and the ability to create (C. Rogers, N.Y. Khryascheva, S.I. Makshanov).

4. Creativity is a natural process which is originated from a strong need in relieving stress, which is caused by situations of uncertainty and incompleteness (J. Guilford, E. Torrance, A. Reber, S. Arieti, R. Corsini, A. Auerbach). 5. Creativity is a "magic synthesis" which unites primitive, irrational strengths of the unconscious with the logical mechanisms of consciousness (P. Hamilnon, T. Huskies).

6. Creativity is a result of economic solutions in the context of the society's economic and time resources necessary for the realization of creative potential. The quality and timeliness of producing these solutions depend on the society's level of development. In accordance with this theory, creativity is regarded in terms of the correlation between the investments, risks and the benefits (Sh. Feldman, J.Robinson, M. Runco).

Despite the high degree of scientific development of the issue, creativity is one of the most questionable and controversial notions in psychology. Scientists still debate if creativity exists or it is a scientific construct. The disagreements in understanding the essence and the structure of creativity reflect the general uncertainty about the nature of creativity. Theoretical conceptualization of creativity historically has undergone the influence of contemporary ideas [2].

In the works by G.A. Bordovsky, N.F. Radionova, V.A. Slastenin, V.A. Izvozchikov, A.P. Tryapitsyna, which are dedicated to modern aspects of the teacher's activity in the rapidly changing society, the focus is on the main issue of pedagogical universities, which is training the professional pedagogue who is able to quickly and efficiently solve problems caused by continuous changes of modern society. This task hugely influences the faculty work, which has undergone significant qualitative changes in the past few years. The development of professional educational standards, making programs and projecting the whole state educational system are realized with faculties' participation. All methodic programs should correspond to learners' (who are future pedagogues) personal qualities and to consistently changing and toughening requirements of the rapidly transforming society permanently facing innovative contemporary ideas [5].

This statement fully agrees with the fact that the transformation of modern society has required the development of the educational system functions. According to the works of Russian well-known pedagogical scientists S.G. Vershlovsky, V.V. Serikov, N.D. Nikandrov, V.A. Slastenin, these new functional specifics of education include the development of students' creative individualism and extensive support of independence. Due to the modern tendencies, the values of the educational system have changed too: self-education, self-perfection, self-development, self-management and self-realization have become highly appreciated.

\section{PROPOSED METHODOLOGY}

The notion "creativity" comprises many mental and personal qualities facilitating the psychological development of creativity. Y.N. Kulutkin believes that beyond all other components of creative thinking the ability to reject the initial hypothesis in the case of its failure and the ability to find new information about an object through involving it into new connections and relations are the most important. Y.A. Ponomarev applied the cognitive activity approach and the system approach to the study of creativity and inferred an important principle of formation, development and realization of creative abilities, which resulted in the SLS-law (stages, levels, steps) claiming that in a psychologically developed behavioral mechanism the stages of its development transform and turn into the structural levels of its organization and appear as functional steps of solving creative tasks. The system factor here is the ability to map out action points in mind, which is determined by a high level of inner vision development. The main specific of the core component of the psychological mechanism of creativity is the unity of the intuitional and the logical [20]. According to Y.A. Ponomarev, the capacity for creativity goes along with two other personal qualities, which are the intensity of the searching motivation and the sensibility to "side" effects of an activity. Thus, the essence of creativity lies in intellectual activity and sensibility to side effects of one's own activity. A creative person can see side effects which accompany the creation of something new whereas an uncreative person can only see intended results and misses the new.

Therefore, Y.A. Ponomarev's theory of creativity allows singling out the following important qualities facilitating 2801 
the process of creativity and, thus, the development of a person's creativity:

psychological flexibility helps the rational and the intuitional aspects of the psyche to easily interact, which facilitates the realization of the whole psychological mechanism of creativity;

the intensity of creative motivation maintains the person's persistence in the search of the new in rather an uncertain, psychologically frustrating situation. This motivation retains the person from an early withdrawal from a creative situation or an escape into the zone of certainty;

the breadth of understanding diverse subject, sociocultural and other contexts allows a person to recognize "side" innovative products of his/her creative search.

V.A. Petrovsky, a representative of the activity-based approach, coined the principle of supra-situational activity to characterize the mechanism of creative activity. The scientist postulates the ability of a person to rise above the situational requirements and set goals which are needless from the point of view of a particular task. Through it, the person overcomes internal and external hurdles ("barriers") of the activity. Thus, V.A. Petrovsky understands creative activity as an excessive activity in regard to motivating activity. Creative activity is characterized by an independent choice, going above the task, modifications of the task and the motive. Thus, creativity is a transformational searching activity which is free from outer stimuli.

D.B. Bogoyavlenskaya also defines creativity as situationally unstimulated activity which tends to break the limits of the given task. This opinion is typical of the activity-based and the synergetic approaches.

D.B. Bogoyavlenskaya believes that the creative personality is a characteristic of all innovators regardless the type of activity. She suggests intellectual activity as an integral organizing factor of creativity, and the latter is seen as an integrated composition which is a personality's property reflecting the process interaction of intellectual and motivating components of the system in their unity and ensuring the personality's ability for situationally unstimulated productive activity.

The experimental studies of creative activity (L.B. Ermolaeva-Tomina) show the variability of its appearance depending on the form and content of the task, its difficulty and provocation to independent solutions. The studies have not result in finding the "general factor" determining the degree of creative capacity, though it has been found out that the exactness and completeness of perception, on the one hand, and the vision of potential transformations of an object and the involvement of a creative element into perception, on the other hand, are optimal for the development of creative thinking.

Thus, a person's creative activity is not connected with the social conditions in which he/she was brought up, not psychophysiologically determined and is not personality typified. The only common features of creative persons are their bright personality and emotional flexibility [14-24].

\section{RESULT ANALYSIS}

The content of the pedagogue's professional creativity can be presented based on the creativity parameters, the study of which was conducted by E. Torrance, D.B. Bogoyavlenskaya, E.E. Tunik, K.O. AbulkhanovaSlavskaya, D. Keifer, J. Averill (see Table 1).

Table 1. The content of the pedagogue's professional creativity

\begin{tabular}{|c|c|c|c|c|}
\hline \multicolumn{5}{|c|}{ The pedagogue's professional creativity } \\
\hline $\begin{array}{l}\text { Compone } \\
\text { nts }\end{array}$ & $\begin{array}{l}\text { Intellectual } \\
\text { creativity }\end{array}$ & $\begin{array}{l}\text { Individual } \\
\text { creativity }\end{array}$ & $\begin{array}{l}\text { Social } \\
\text { creativity }\end{array}$ & $\begin{array}{l}\text { Emotional } \\
\text { creativity }\end{array}$ \\
\hline Content & $\begin{array}{l}\text { Originalit } \\
\text { y, } \\
\text { flexibility, } \\
\text { velocity, } \\
\text { developm } \\
\text { ent, } \\
\text { richness } \\
\text { and } \\
\text { brightness } \\
\text { of } \\
\text { associatio } \\
\text { ns }\end{array}$ & $\begin{array}{l}\text { Imaginati } \\
\text { on, } \\
\text { difficulty } \\
\text { of self- } \\
\text { expressio } \\
\text { n, } \\
\text { curiosity, } \\
\text { impulsivi } \\
\text { ty, } \\
\text { need in } \\
\text { creation }\end{array}$ & $\begin{array}{l}\text { Expressi } \\
\text { on, } \\
\text { flexibilit } \\
\text { y of the } \\
\text { creative } \\
\text { process, } \\
\text { sensibilit } \\
\text { y to } \\
\text { social } \\
\text { phenome } \\
\text { na }\end{array}$ & $\begin{array}{l}\text { Novelty, } \\
\text { efficienc } \\
\text { y of the } \\
\text { creation } \\
\text { and } \\
\text { assessme } \\
\text { nt, the } \\
\text { uniquene } \\
\text { ss of } \\
\text { emotion } \\
\text { al states }\end{array}$ \\
\hline
\end{tabular}

Separating inside the structure of professional creativity such elements as intellectual, personal, social and emotional creativity results from the specifics of the pedagogue's professional activity. On the other hand, the study of the pedagogue's professional activity results in the following conclusions, which build the basis of the pedagogical creativity structure and help make the definition of professional creativity more precise:

the psychological profession as a profession of the "person-to-person" type is socially oriented, which implies a high level of the social intellect. In its turn, social creativity is a specific product of the social intellect positioned as divergent thinking in the sphere of social and communicative situations. Therefore, we consider that social creativity is a valid component of professional creativity;

a large majority of scientists consider the psychological profession to be personality-oriented and, therefore, requiring well-developed personal qualities. Individual creativity is a kind of creative expression of the personality. K.O. Abulkhanova-Slavskaya says that expression of personality is necessary for the pedagogue's effective performance. In this connection we tend to believe that this is a proper parameter in the structure of professional creativity. This quality matches A. Maslow's creativity of self-actualization;

- psychological activity requires the specialist's developed emotional sphere, emphatic abilities, understanding people's emotions and feelings. This ability to create new, original emotional states (J. Averill) is necessary for effective involvement into the psychological profession. Guided by the above-mentioned arguments we consider emotional creativity to be reasonably included 
into the structure of professional creativity.

intellectual creativity, i.e. divergent thinking, is the basis of any manifestation of creativity, and its presence in the structure of professional creativity is axiomatic.

The interaction of these components composes a new quality which can be defined as the pedagogue's professional creativity. This structure of professional creativity is determined by the specifics of professional activity and the pedagogue's professionally important qualities.

The analysis and generalization of the existing approaches to the study of professional creativity and the pedagogue's professionally important qualities allows us to define the notion of professional creativity more exactly. The pedagogue's professional creativity is the ability to generate many diverse original ideas in unconventional conditions of educational activity. It is a dynamic component of professionally important pedagogue's qualities, which includes the intellectual, individual, social and emotional components, whose composite development influences the effectiveness of the pedagogue's performance and its development. This is the pedagogue's professional creativity which is that very form of realized creative abilities which directly influences the educational process and which represents the necessary level of their development for an effective realization of modern educational technologies. Therefore, professional creativity can be seen as the highest level of creative abilities development in a professional sphere, and the highest level of the pedagogue's creative competence.

Based on the diagnosis results of the study into the strength and depth of the interconnections between the structural components of professional creativity we carried out a comparative analysis, the results of which are presented in Tables 2 and 3 .

Table 2. Interconnections between composite parameters of creativity in the experimental group at the diagnostic stage of the experiment

\begin{tabular}{|l|c|c|c|c|}
\hline $\begin{array}{l}\text { Paramete } \\
\text { ss }\end{array}$ & $\begin{array}{c}\text { Intellectu } \\
\text { al } \\
\text { creativity }\end{array}$ & $\begin{array}{c}\text { Individu } \\
\text { al } \\
\text { creativit } \\
\mathrm{y}\end{array}$ & $\begin{array}{c}\text { Social } \\
\text { creativit } \\
\mathrm{y}\end{array}$ & $\begin{array}{c}\text { Emotion } \\
\text { al } \\
\text { creativity }\end{array}$ \\
\hline $\begin{array}{l}\text { Intellectua } \\
\text { l creativity }\end{array}$ & 0.729 & 0.735 & 0.631 \\
\hline $\begin{array}{l}\text { Individual } \\
\text { creativity }\end{array}$ & 0.729 & 0.593 & 0.593 & 0.711 \\
\hline $\begin{array}{l}\text { Social } \\
\text { creativity }\end{array}$ & 0.735 & 0.711 & 0.633 & 0.633 \\
\hline $\begin{array}{l}\text { Emotional } \\
\text { creativity }\end{array}$ & 0.631 & & & \\
\hline \multicolumn{2}{|c|}{$\boldsymbol{0 . 0 5}$} & & & \\
\hline
\end{tabular}

The analysis of the results in Table 2 leads to a conclusion about a strong interconnection between all composite parameters of the pedagogues' creativity in the experimental group. It can be noticed that intellectual creativity has the strongest connections with the other parameters whereas social and emotional creativity have the weakest connections. Intellectual and social creativity demonstrate the strongest level of connection, with $\mathrm{t}=$ $0.735, \mathrm{p} \leq 0.05$ whereas individual and social creativity show the weakest one, with $\mathrm{t}=0.593, \mathrm{p} \leq 0.05$. Taking into consideration the fact that all composite parameters correlate with each other having the "strength of connection" indicator higher than 0.55 , we can claim that the connections between all the components of creativity in the experimental group are firm. Though, it is early at this stage to say if professional creativity is a united factor or not.

Table 3. Interconnections between composite parameters of creativity in the control group at the diagnostic stage of the experiment

\begin{tabular}{|l|c|c|c|c|}
\hline $\begin{array}{l}\text { Paramete } \\
\text { rs }\end{array}$ & $\begin{array}{c}\text { Intellectu } \\
\text { al } \\
\text { creativity }\end{array}$ & $\begin{array}{c}\text { Individu } \\
\text { al } \\
\text { creativit } \\
\mathrm{y}\end{array}$ & $\begin{array}{c}\text { Social } \\
\text { creativit } \\
\mathrm{y}\end{array}$ & $\begin{array}{c}\text { Emotion } \\
\text { al } \\
\text { creativity }\end{array}$ \\
\hline $\begin{array}{l}\text { Intellectua } \\
\text { l creativity }\end{array}$ & 0.718 & 0.713 & 0.647 \\
\hline $\begin{array}{l}\text { Individual } \\
\text { creativity }\end{array}$ & 0.718 & 0.526 & 0.526 & 0.696 \\
\hline $\begin{array}{l}\text { Social } \\
\text { creativity }\end{array}$ & 0.713 & 0.696 & 0.641 & 0.641 \\
\hline $\begin{array}{l}\text { Emotional } \\
\text { creativity }\end{array}$ & 0.647 & & & \\
\hline
\end{tabular}

$p \leq 0.05$

The analysis of the results presented in Table 3 manifests a strong connection of all the composite components of pedagogues' creativity in the control group. Comparing the results of the experimental and control groups we can see that the character of connections is similar, i.e. intellectual creativity is the most connected with the other parameters whereas emotional and social creativity demonstrate the weakest connections. The difference in the "strength of connection" indicators is under 0.7, which is not a considerable extent.

\section{CONCLUSION}

Nowadays pedagogy witnesses the search of the most efficient innovative technologies facilitating the development of a creative personality, and in regard of language education - the formation and further development of the foreign language competence and the pedagogue's linguistic creativity, which is expressed through the ability to use original linguistic means and ways of rendering thoughts in a foreign language in the conditions of growing international collaboration at different levels of intercultural contacts and exchanges.

The content of teaching foreign languages comprises the development of professionally oriented foreign language communication competence, a high level of which is necessary for solving tasks of interpersonal and international character, for scientific research work and for 
further professional activity. The necessity to meet this target makes modern teachers intensely and creatively seeks for didactic materials for the organization of the educational process which will help to form the learners' positive and continuous motivation to the study of the foreign language, personal growth and the scope for creative professional self-realization, which is necessary for modern specialists. Teaching foreign languages is a dynamic process. The teacher of foreign language should position him/herself as a thinking practitioner using such state-of-the-art pedagogical technologies which would make the process of teaching not only modern and effective, but also meeting the learner's growing interests and satisfying their needs and expectations about their final results, i.e. the level of their future proficiency. Therefore, the pedagogue's high proficiency level, his/her pedagogical creativity, innovative thinking aimed at qualitative changes in the system of the subject teaching through the practical usage of innovative teaching methods and forms as well as information communicative technologies are the key to success. The usage of effective pedagogical technologies very often determines the quality and the result of teaching [4].

So we believe that the achievement of the main goal of teaching foreign languages rests in the move from traditional algorithmic teaching forms and methods to creative ones, aimed at providing more freedom and the development of learners' creative potential through the usage of interactive teaching forms. The development of creative personality should start in the first university year. M.M. Zinovkina, characterizing the continuity and consistency of creativity development, wisely says that multilevel continuous creative teaching the final goal of which is a highly-developed, physically healthy, creative personality is the most favorable.

We hold the view that active methods of teaching foreign languages are very similar to creative methods which involve creative, challenging tasks in the learning activity. Modern creative teaching methods are the methods which are aimed at the formation and development of learners' ability to think constructively and originally and to make a new product.

\section{REFERENCES}

1. Abuzjarova M.I. (2018). Tendencies, law of development and economic content of innovative entrepreneurship. Modern Economy Success. Issue. 1. P. 43-50.

2. Ashmarov I.A. (2018). Some approaches to the study of the USSR' military economy in the soviet and russian national historiography. Historical Bulletin. Vol. 1. Issue 2. P. $19-31$.

3. Aminova D. K., \& Tsakhaeva, A. A. (2018). Effective preparation of the future psychologist as one of the elements of the security education system. International Journal of Medicine and Psychology. Vol. 1. Issue 3. P. 40 - 47.

4. Badakhova I.T. (2017). Formation of professionally significant qualities of future managers in the training process forming. Modern Scientist. Issue 7. P. $81-84$.
5. Bolotin I.S., Mikhaylov A.A., Sorokina N.D. (2017). Functional literacy of students in terms of introduction of information technologies (on the example of research among the students of MAI). Modern Scientist. Vol. 1. Issue 1. P. 160-163.

6. Borisova M.V., Musokhranov A.Yu., Sidorova N.A. (2018). Use of fitness directions elements on physical education classes and their psychomatic impact on students of the special medical group. Modern Scientist. Issue 1. P. 6 - 9 .

7. Borovikova T.V. (2017). Methodological bases of formation of the intellectual potential of territories in the conditions of innovative economy. Modern Economy Success. Issue 6. P. $46-49$.

8. Gadzaov A.F., Dzerzhinskaya M.R. (2018). Mathematical methods of analysis of the periodic components of economic processes. Modern Economy Success. Issue 1. P. $14-18$.

9. Gadzhieva U.B. (2018). Socialization of personality as a factor in the mental, intellectual and spiritual-moral development. International Journal of Medicine and Psychology. Vol. 1. Issue 2. P. $17-20$.

10. Gasanova P.G., Daudova D.M, Kabieva R.A., Tsahaeva A.A. (2017). Moral qualities of businessmen in public con-sciousness. Modern Scientist. Vol. 1. Issue 1. P. $209-211$.

11. Gnatyuk S.N., Pekert N.A. (2018). Education as a factor of sustainable development of agriculture. Russian Economic Bulletin. Vol. 1. Issue 3. P. 18 - 27.

12. Kryuchkova K.S. (2018) Modular training of future teachers with the use of information technologies in the conditions of virtual academic mobility. Modern Humanities Success. Issue 4. P. 9 - 14.

13. Kuznetsov A.A., Ignatyeva T.A., Kuznetsov A.O. (2018). Strategy and key elements of competitiveness. Modern Economy Success. Issue 1. P. 25 - 29.

14. Narkevich, L.V., Narkevich, E.A. (2018). Financial condition analysis in the crisis management system. Russian Economic Bulletin. Vol. 1. Issue 4. P. 10 -24 .

15. Osipova M.B. (2018). Tendencies of development of educational practice of the modern educational organizations. Modern Humanities Success. Issue 1. P. $10-13$.

16. Popov V.P. (2018). Methodological aspects of teaching economic disciplines in a multi-level system of education. Modern Humanities Success. Issue 3. P. $10-$ 16.

17. Schwarzkopf N.V. (2018). Improving the use of data mining technology as a way of reducing credit risk. Russian Economic Bulletin. Vol. 1. Issue 1. P. 10 18.

18. Sergeeva M.G., Trubakova D.I. (2017). Teacher's Reflection Formation as Factor of Effectiveness Children's Social Intelligence Forming. Modern Scientist. Issue 7. P. 62 - 64.

19. Tsahaeva A.A., Aminov U.K., Aminova D.K. (2017). Driving forces of the development of adaptive behavior of personality: methodological considerations. Modern Scientist. Issue 8. P. $44-47$. 
20. Anwar M.S.M., Shilova V.S., Serebrennikova, A.V., Minyazeva, T.F., Inogamova Khegay L.V., Tsakhaeva A.A. (2019). Environmental component in the modern specialists training. Religacion. Revista De Ciencias Sociales Y Humanidades, Vol. 4, No. 18, 238 - 244.

21. Pichugina V., Volkova Y. (2019). Anthropology of ancient polis: urban landscapes and practices. An international seminar. Schole: Schole: Ancient Philosophy and the Classical Tradition, Vol. 13, Issue 1, 382-386.

22. Samokhin, I. S., Komarovskaya, E. P., Chernov, A. V., Sergeeva, M. G. (2019). "Lapel Pins for Suffering" in the System of Official Awards of the XX-XXI Centuries. Nauchnyi dialog, 10, 452-464.

23. Sergeeva M.G., Stanchuliak T.G., Borovikova Ya.V., Zhirkova G.P., Budiltseva M.B., Mamaeva S.V., Shmulskaya L.S. (2019). Modern technologies of professional teaching in the system of life-long learning. Religación. Revista De Ciencias Sociales Y Humanidades, 4(16), $454-464$.

24. Sergeeva, M.G., Stanchuliak, T.G., Yulina, G.N., Shishov, S.E., Skaramanga, V.P., Sklyadneva, V.V., Orlova I.K., Forming students' content and language competence in the conditions of a non-linguistic higher educational institution (2019). Revista Inclusiones, 6,126 $-134$.

https://doi.org/10.25205/1995-4328-2019-13-1-382-385
25. Zarudnaya M.V., Fominykh N.Y., Enygin D.V., Kudysheva A.A., Epifanov D.A., Eferova A.R. Methodological Approaches to University Instructors Professional Foreign Languages Competence Development. The Journal of Social Sciences Research. 2018. № 5 Special Issue. P. 375 - 381. https://doi.org/10.32861/jssr.spi5.375.381

26. Bakyt T. Kuanysheva, Rakhila Zh. Aubakirova, Nelli Iu. Pigovayeva \& Nataliia Iu. Fominykh Technologization of the Pedagogical Process as a Teacher Self-Improvement Factor. Journal of Social Studies Education Research. 2019. № 10. P. 404 - 433.

27. S.V.R.K.Rao, M.Saritha Devi, A.R.Kishore and Praveen Kumar Wireless sensor Network based Industrial Automation using Internet of Things (IoT). International Journal of Advanced Trends in Computer Science and Engineering. 2018. Volume 7 No. 6 (2018). Pages 82-86 https://doi.org/10.30534/ijatcse/2018/01762018

28. Ramakrishna Rath, R.Tamilkodi, K V Mishra and K Jose Cherian Utilizing Contemporary Benchmark Protocol for Sharing Mobile Ad-hoc Network Environment. International Journal of Advanced Trends in Computer Science and Engineering. 2018. Volume 7 No. 6 (2018). Pages 96-98

https://doi.org/10.30534/ijatcse/2018/04762018 